\title{
Yangia pacifica gen. nov., sp. nov., a novel member of the Roseobacter clade from coastal sediment of the East China Sea
}

Correspondence

Shuang-Jiang Liu

shuangjiang@hotmail.com

\author{
Xin Dai, ${ }^{1}$ Bao-Jun Wang, ${ }^{1}$ Qing-Xiang Yang, ${ }^{2}$ Nian-Zhi Jiao ${ }^{2}$ \\ and Shuang-Jiang Liu ${ }^{1}$
${ }^{1}$ State Key Laboratory of Microbial Resources, Institute of Microbiology, Chinese Academy of Sciences, Zhong-Guan-Cun, Haidian, Beijing 100080, China China \\ ${ }^{2}$ State Key Laboratory for Marine Environmental Sciences, Xiamen University, Xiamen, 361005,
}

An aerobic, Gram-negative bacterial isolate, strain $D X 5-10^{\top}$, was isolated from coastal sediment of the East China Sea. The taxonomy of strain DX5 $10^{\top}$ was studied by phenotypic and phylogenetic methods. Strain DX5-10 $10^{\top}$ was motile, formed faint-yellowish colonies and was positive for catalase reaction and weakly positive for oxidase reaction. The nearly complete $16 \mathrm{~S}$ rRNA gene of strain DX5-10 $0^{\top}$ was obtained and sequence analysis indicated that strain DX5-10 $0^{\top}$ represented an independent lineage within the Roseobacter clade of Alphaproteobacteria. Strain DX5 $-10^{\top}$ was phylogenetically related to members of the genera Roseobacter, Loktanella, Roseisalinus, Silicibacter, Antarctobacter, Sulfitobacter, Salipiger, Ruegeria and Roseivivax, and the sequence identities among them were less than $95.0 \%$. The predominant respiratory ubiquinone of strain DX5-10 $0^{\top}$ was $Q-10$ and the DNA $G+C$ content of strain DX5-10 $0^{\top}$ was $63.3 \mathrm{~mol} \%$. Therefore, strain $\mathrm{DX} 5-10^{\top}$ represents a novel species of a novel genus, for which the name Yangia pacifica gen. nov., sp. nov. is proposed, with the type strain DX5-10 $\left(=\right.$ CGMCC $\left._{1.3455^{\top}}=\mathrm{JCM} 12573^{\top}\right)$.
Members of the Roseobacter clade are aerobic, Gramnegative bacteria and have been widely detected in marine or saline lacustrine samples by ribosomal probing (González \& Moran, 1997; Zubkov et al., 2001) and 16S rRNA gene cloning (Eilers et al., 2000; Rappé et al., 2000). Bacterial species that belong to the Roseobacter clade have been frequently isolated from such environments. The Roseobacter clade within the order Rhodobacterales contains 33 genera (Garrity et al., 2004), and recently several novel genera, including Oceanicola (Cho \& Giovannoni, 2004), Loktanella (Van Trappen et al., 2004), Salipiger (Martínez-Cánovas et al., 2004), Roseisalinus (Labrenz et al., 2005) and Thalassobacter (Macián et al., 2005), have been established. The physiological characterization of described species within these genera indicates that they are metabolically diverse and are potentially important players in the degradation of lignin and aromatic compounds (Buchan et al., 2001) and in biogeocycling of organic (González et al., 2003) or inorganic

Published online ahead of print on 28 October 2005 as DOI 10.1099/ ijs.0.64013-0.

Abbreviation: Bchl a, bacteriochlorophyll a.

The GenBank/EMBL/DDBJ accession number for the 16S rRNA gene sequence of Yangia pacifica DX5-10 $10^{\top}$ is AJ877265. sulfur-containing compounds (Sorokin, 1995; Pukall et al., 1999).

During an ecological survey of microbial diversity of coastal sediments, an aerobic, Gram-negative bacterium, strain DX5 $-10^{\mathrm{T}}$, was obtained that is phylogenetically related to members of the genera Roseobacter, Loktanella, Roseisalinus, Roseivivax, Salipiger, Silicibacter and Sulfitobacter. This bacterial strain, together with some uncharacterized marine isolates (Teske et al., 2000; Buchan et al., 2001), formed a distinct lineage within the Roseobacter clade. In this note, we describe the characterization and classification of strain DX5- $10^{\mathrm{T}}$.

Strain DX5 $-10^{\mathrm{T}}$ was isolated from coastal sediment of the East China Sea located in Fujian Province. The sample (from 4-6 cm beneath the surface) was diluted with $9 \mathrm{ml}$ sterile saline solution and $0 \cdot 1 \mathrm{ml} 10^{-3}$ and $10^{-4}$ dilutions were plated onto artificial sea water basal medium with $1 \%$ peptone and $0.5 \%$ yeast extract (Eguchi et al., 1996). Routine cultivation of strain DX5- $10^{\mathrm{T}}$ was done at $30{ }^{\circ} \mathrm{C}$ in marine broth 2216 (MB; Difco). Methods for observation of morphology, physiological and biochemical tests, including catalase and oxidase reactions, nitrate reduction, requirement for $\mathrm{NaCl}$, ranges of temperature and $\mathrm{pH}$ for growth, decomposition of gelatin and casein and hydrolysis of starch 
were described and cited in a previous report (Dai et al., 2005).

Biomass for chemotaxonomic analysis was harvested from $\mathrm{MB}$ cultures on a rotary shaker $\left(100\right.$ r.p.m., $\left.30^{\circ} \mathrm{C}\right)$. Quinones were extracted and purified according to Collins (1985) and were analysed by HPLC equipped with a Hewlett Packard 1050 system and a Zorbax ODS column (Agilent Technologies) operating at $40^{\circ} \mathrm{C}$, with Ruegeria gelatinovorans DSM $5887^{\mathrm{T}}$ as reference strain. The mobile phase was a mixture of acetonitrile/2-propanol $(2: 1 \cdot 2)$ with a flow rate of $1 \mathrm{ml} \mathrm{min}{ }^{-1}$. The UV detection wavelength was set at $270 \mathrm{~nm}$. The fatty-acid profile of whole cells was analysed by gas chromatography by using a model HP6890GC equipped with a hydrogen-ionization detector. Peaks were identified with pre-installed software, HPCHEM-STATION (version A5.01).

Genomic DNA of strain DX5- $10^{\mathrm{T}}$ was extracted according to Marmur (1961) and G+C content was determined by thermal denaturation. The 16S rRNA gene of strain DX5$10^{\mathrm{T}}$ was amplified and sequenced as described previously (Zhang et al., 2003). Alignments of $16 \mathrm{~S}$ rRNA gene sequences of strain DX5 $-10^{\mathrm{T}}$ and species of the Roseobacter clade (Fig. 1) were carried out with CLUSTAL X program (version 1.8; Thompson et al., 1997). Phylogenetic trees were constructed using the neighbour-joining method (Saitou \& Nei, 1987) with the Kimura two-parameter model (Kimura,
1980 ) by using the programs of TREECON (Van de Peer \& De Wachter, 1994).

Bacteriochlorophyll $a$ (Bchl $a$ ) was detected spectrophotometrically in vivo and in vitro. For in vivo measurements, $5 \mathrm{ml}$ of strain DX5-10 ${ }^{\mathrm{T}}$ culture in MB incubated under a natural daylight rhythm was collected, washed and resuspended in $5 \mathrm{ml} \mathrm{PBS}\left(137 \mathrm{mmol} \mathrm{NaCl} \mathrm{l} \mathrm{l}^{-1}, 2 \cdot 7 \mathrm{mmol}\right.$ $\mathrm{KCl} l^{-1}, 4 \cdot 3 \mathrm{mmol} \mathrm{Na} \mathrm{HPO}_{4} .7 \mathrm{H}_{2} \mathrm{Ol}^{-1}, 1 \cdot 4 \mathrm{mmol} \mathrm{KH}{ }_{2} \mathrm{PO}_{4}$ $\mathrm{l}^{-1}, \mathrm{pH} 7 \cdot 8$ ). For in vitro measurements, $5 \mathrm{ml}$ liquid culture was centrifuged at $5000 \mathrm{~g}$ for $10 \mathrm{~min}$. The cells were lysed in liquid nitrogen and Bchl $a$ was extracted using $5 \mathrm{ml}$ ice-cold acetone/methanol solution $(7: 2, \mathrm{v} / \mathrm{v})$ in the dark at $-20{ }^{\circ} \mathrm{C}$ for $12 \mathrm{~h}$. Cell fragments were then removed by centrifugation. Spectrophotometric measurements were performed with an HP8453 UV/Vis spectrometer by scanning the wavelength range 400-900 $\mathrm{nm}$. Pigments were detected using HPLC Angilent (ODS column: $5 \mu \mathrm{m}, 4 \times 250 \mathrm{~mm}$; UV2000 detector $\lambda=362 \mathrm{~nm}$ ) as described by Kobližek et al. (2003). Roseobacter litoralis DSM $6996^{\mathrm{T}}$ was used as a control.

Strain DX5- $10^{\mathrm{T}}$ formed faint-yellowish colonies on $\mathrm{MB}$ agar. Cells of strain DX5-10 ${ }^{\mathrm{T}}$ were motile, Gram-negative rods $(0.8 \times 1.0-1.5 \mu \mathrm{m}$ in size $)$. The catalase reaction was positive and oxidase reaction was weakly positive. Growth occurred at temperatures of $22-40^{\circ} \mathrm{C}$ and at $\mathrm{pH} 5 \cdot 0-10 \cdot 0$, with optima at $37^{\circ} \mathrm{C}$ and $\mathrm{pH} 7 \cdot 5 . \mathrm{NaCl}$ was required but

Table 1. Comparison of fatty-acid compositions of strain DX5-10 $0^{\top}$ with some type species of the family Rhodobacteraceae

Values are percentages of total fatty acids and only percentages higher than $1 \%$ are shown; -, negative or percentages lower than $1 \%$; ND, no data available. Species/strains: 1, Yangia pacifica sp. nov. DX5$10^{\mathrm{T}}$; 2, Salipiger mucosus A3 ${ }^{\mathrm{T}}$ (data from Martínez-Cánovas et al., 2004); 3, Roseivivax halodurans OCh $239^{\mathrm{T}}$ (Suzuki et al., 1999; Martínez-Cánovas et al., 2004); 4, Loktanella salsilacus (10 strains) (Van Trappen et al., 2004); 5, Oceanicola granulosus HTCC $2516^{\mathrm{T}}$ (Cho \& Giovannoni, 2004); 6, Roseisalinus antarcticus EL-88 ${ }^{\mathrm{T}}$ (Labrenz et al., 2005); 7, Ketogulonicigenium vulgare DSM $4025^{\mathrm{T}}$ (Urbance et al., 2001); 8, Antarctobacter heliothermus EL-219 $9^{\mathrm{T}}$ (Labrenz et al., 1998).

\begin{tabular}{|lcccccccc|}
\hline Fatty acid & $\mathbf{1}$ & $\mathbf{2}$ & $\mathbf{3}$ & $\mathbf{4}$ & $\mathbf{5}$ & $\mathbf{6}$ & $\mathbf{7}$ & $\mathbf{8}$ \\
\hline $10: 03-\mathrm{OH}$ & - & - & - & $2 \cdot 4$ & $1 \cdot 5$ & $1 \cdot 9$ & $3 \cdot 6$ & - \\
$12: 03-\mathrm{OH}$ & $3 \cdot 20$ & - & - & - & $1 \cdot 6$ & - & $2 \cdot 9$ & - \\
$12: 13-\mathrm{OH}$ & - & $2 \cdot 3$ & - & $\mathrm{ND}$ & - & - & - & $3 \cdot 1$ \\
$14: 0$ & - & - & - & - & - & - & $2 \cdot 4$ & - \\
$16: 0$ & $8 \cdot 95$ & $12 \cdot 4$ & - & $2 \cdot 9$ & $11 \cdot 9$ & $15 \cdot 1$ & $33 \cdot 5$ & $2 \cdot 5$ \\
$15: 0-\mathrm{iso} 2-\mathrm{OH} / 16: 1 \omega 7 c$ & $3 \cdot 93^{*}$ & $1 \cdot 3^{*}$ & - & $2 \cdot 8$ & $1 \cdot 2$ & $2 \cdot 1^{*}$ & $2 \cdot 7$ & - \\
$17: 0$ & $1 \cdot 44$ & - & - & - & - & - & - & - \\
$17: 1 \omega 8 c$ & $3 \cdot 93$ & - & - & - & - & - & - & - \\
$18: 0$ & - & $2 \cdot 0$ & - & $1 \cdot 4$ & - & $2 \cdot 3$ & $2 \cdot 9$ & $1 \cdot 0$ \\
$18: 1 \omega 7 c / \omega 9 c / \omega 12 t$ & $81 \cdot 67$ & $78 \cdot 0 \dagger$ & Not & $87 \cdot 7 \dagger$ & $62 \cdot 8 \dagger$ & $62 \cdot 0 \dagger$ & $52 \cdot 0$ & $83 \cdot 2$ \\
& & & quantified & & & & & \\
Methyl $18: 1$ & - & $1 \cdot 9$ & - & - & $8 \cdot 1$ & - & - & - \\
cyclo $19: 0$ & - & $2 \cdot 3$ & - & ND & $10 \cdot 8$ & - & - & $2 \cdot 4$ \\
\hline
\end{tabular}

${ }^{\star}$ Fatty acid $16: 1 \omega 7 c$.

$\dagger$ Fatty acid $\omega 7 c$. 
concentrations greater than $13 \%$ were inhibitory to growth. Maximal growth was observed at $5 \% \mathrm{NaCl}$. Bchl $a$ was not detected either in vivo or in vitro. Additional phenotypic properties are given in the following genus and species description. The cells of strain DX5- $10^{\mathrm{T}}$ contained ubiquinone $10(\mathrm{Q}-10)$. The fatty-acid profile of strain DX5-10 ${ }^{\mathrm{T}}$ grown in $\mathrm{MB}$ is detailed in the species description and in Table 1 . The genomic DNA G + C content was $63 \cdot 3 \mathrm{~mol} \%$. A list of properties that differentiate strain DX5 $-10^{\mathrm{T}}$ from some related members of the Roseobacter clade is provided in Tables 1 and 2. In brief, strain DX5-10 ${ }^{\mathrm{T}}$ was different from members of the genera Roseivivax and Salipiger in that Bchl $a$ was not detected either in vivo or in vitro (Table 2). Furthermore, strain DX5-10 ${ }^{\mathrm{T}}$ contained $17: 1 \omega 8 c(3 \cdot 93 \%)$ and $17: 0(1.44 \%)$, which were not detected in any other genera as listed in Table 1, and the fatty acid methyl ester

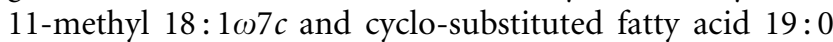
cyclo $\omega 8 c$ that were present in Salipiger mucosus $\mathrm{A}^{\mathrm{T}}$ were not detected in strain DX5-10 .

The nearly complete 16S rRNA gene of strain DX5- $10^{\mathrm{T}}$ was amplified and partially sequenced (1351 bp). A BLASTN search with the $16 \mathrm{~S}$ rRNA gene sequence of strain DX5-10 ${ }^{\mathrm{T}}$ in the GenBank database and phylogenetic analysis based on 16S rRNA gene sequence identities showed that strain DX5- $10^{\mathrm{T}}$ was related to species of various genera: Roseobacter gallaeciensis $\mathrm{BS} 107^{\mathrm{T}}(95 \cdot 0 \%)$, Loktanella hongkongensis JCM $12479^{\mathrm{T}}(94 \cdot 7 \%)$, Roseisalinus antarcticus EL-88 $(94.5 \%)$, Silicibacter pomeroyi DSS-3 $3^{\mathrm{T}}(94 \cdot 5 \%)$, Antarctobacter heliothermus EL-219 ${ }^{\mathrm{T}}$ (94.2\%), Sulfitobacter dubius KMM $3554^{\mathrm{T}}(94 \cdot 2 \%)$, Salipiger mucosus $\mathrm{A3}^{\mathrm{T}}(94 \cdot 1 \%)$, Ruegeria atlantica IAM $14463^{\mathrm{T}}(94 \cdot 0 \%)$ and Roseivivax halodurans OCh $210^{\mathrm{T}}(93 \cdot 9 \%)$. Following these discoveries, a detailed phylogenetic analysis on the species with validly published names of the Roseobacter clade and strain DX5$10^{\mathrm{T}}$ was performed, and the phylogenetic tree based on the nearly complete $16 \mathrm{~S}$ RNA gene sequence (1324 bp) similarity indicates that strain DX5-10 $0^{\mathrm{T}}$, together with previously isolated but not taxonomically described strains NF18, AG33 and SE45 (Teske et al., 2000; Buchan et al., 2001), formed an independent lineage representing a novel genus within the Roseobacter clade (Fig. 1). This lineage represented by strain DX5- $10^{\mathrm{T}}$ is the neighbour to the clade of the species of Roseivivax and Salipiger mucosus $\mathrm{A}^{\mathrm{T}}$ (Fig. 1), and the 16S rRNA gene identities of strain DX5-10 ${ }^{\mathrm{T}}$ between them ranged from $93 \cdot 7$ to $94 \cdot 1 \%$.

Combining the phenotypic and phylogenetic studies, we propose that strain DX5- $10^{\mathrm{T}}$ represents a novel species of a novel genus, Yangia pacifica gen. nov., sp. nov.

\section{Description of Yangia gen. nov.}

Yangia (Yan'gi.a. N.L. fem. n. Yangia after the Chinese microbiologist H.-F. Yang, who founded the research of environmental microbiology in the early 1960s in China).

Gram-negative rods, motile. Aerobic heterotroph. When grown on marine agar 2216 plates, small, wettish, shiny, faint-yellowish colonies develop within 3-5 days. Cells do not form spores. Growth requires $\mathrm{NaCl}$. Catalase reaction is positive and oxidase reaction is weakly positive. The predominant respiratory quinone is Q-10. Major fatty acids are $18: 1$ and $16: 0$. Cells also contain 3-hydroxylated $12: 0$. The type species is Yangia pacifica.

\section{Description of Yangia pacifica sp. nov.}

Yangia pacifica (pa.ci'fi.ca N.L. fem. adj. pacifica pertaining to the Pacific Ocean, the origin of the type strain).

In addition to the properties described above for the genus, the following properties are observed. Cells are $0 \cdot 8 \times 1 \cdot 0$ $1.5 \mu \mathrm{m}$ in size and tend to aggregate after cell division.

Table 2. Characteristics that differentiate Yangia pacifica gen. nov., sp. nov. from related genera

Genera: 1, Salipiger (data from Martínez-Cánovas et al., 2004); 2, Roseivivax (Suzuki et al., 1999); 3, Loktanella (Van Trappen et al., 2004); 4, Oceanicola (Cho \& Giovannoni, 2004); 5, Roseisalinus (Labrenz et al., 2005); 6, Ketogulonicigenium (Urbance et al., 2001); 7, Antarctobacter (Labrenz et al., 1998). +, Positive; -, negative; W, weakly positive; ND, no data available.

\begin{tabular}{|c|c|c|c|c|c|c|c|c|}
\hline Characteristic & DX5-10 ${ }^{\mathrm{T}}$ & 1 & 2 & 3 & 4 & 5 & 6 & 7 \\
\hline Colony colour & Faint yellow & - & Pink & Pink-beige & Faint yellow & Red & Tan & Brown-yellow \\
\hline Oxidase & $\mathrm{W}$ & + & + & + & + & + & + & + \\
\hline Bchl $a$ & - & - & + & $\mathrm{ND}$ & - & + & - & - \\
\hline $\mathrm{Na}^{+}$requirement & + & + & - & $+1-$ & + & + & - & + \\
\hline Optimum temperature $\left({ }^{\circ} \mathrm{C}\right)$ & 37 & $20-40$ & $27-30$ & 25 & $28-30$ & $16-26$ & $27-31$ & $16-26$ \\
\hline Nitrate to nitrite & - & - & $+1-$ & - & - & + & ND & + \\
\hline Acids from glucose & - & - & $+/ \mathrm{w} /-$ & $\mathrm{ND}$ & - & - & $\mathrm{ND}$ & - \\
\hline Quinone type & Q-10 & Q-10 & Q-10 & $\mathrm{ND}$ & $\mathrm{ND}$ & Q-10 & $\mathrm{ND}$ & Q-10 \\
\hline DNA G $+C$ content $(\mathrm{mol} \%)$ & $63 \cdot 3$ & $64 \cdot 5$ & $59 \cdot 7-64 \cdot 4$ & $59 \cdot 4-66 \cdot 4$ & $67 \cdot 3-71 \cdot 5$ & 67 & $52 \cdot 1-54 \cdot 0$ & $62 \cdot 3-62 \cdot 8$ \\
\hline
\end{tabular}




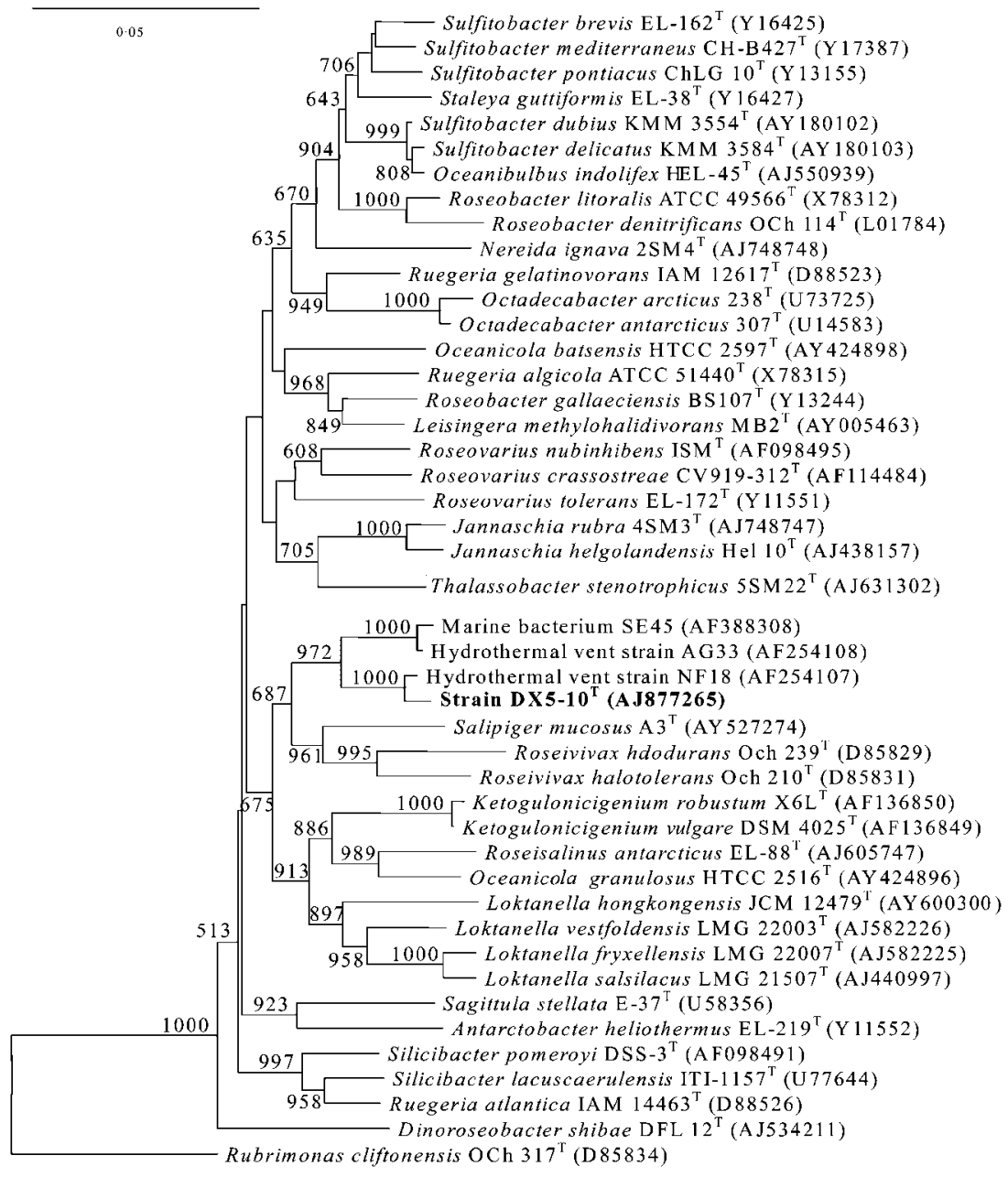

Fig. 1. Neighbour-joining tree based on 16S rRNA gene sequence analysis indicates that strain $\mathrm{DX} 5-10^{\top}$, hydrothermal vent strains NF18 and AG33, and marine isolate SE45 (Buchan et al., 2001; Teske et al., 2000) form a coherent cluster within the Roseobacter clade, representing the novel genus Yangia. Rubrimonas cliftonensis OCh $317^{\top}$ (D85834) was used as the outgroup. Bootstrap confidence values obtained from 1000 bootstrap replications are given at nodes. Bar, 0.05 substitutions per nucleotide position.
Strictly aerobic; does not grow under anaerobic conditions. Cells grow at $22-40{ }^{\circ} \mathrm{C}$ and at $\mathrm{pH} 5 \cdot 0-10 \cdot 0$, with optima at $37^{\circ} \mathrm{C}$ and $\mathrm{pH} 7 \cdot 5 . \mathrm{NaCl}$ is required and the species grows in the $\mathrm{NaCl}$ concentration range of $1-10 \%$ (optimal growth occurs at $5 \% \mathrm{NaCl}$ ). Bchl $a$ is not detected either in vivo or in vitro. Nitrate reduction, hydrolysis of starch, gelatin liquefaction and indole formation are negative. Accumulates poly-(3-hydroxybutyric) acids. Urease formation is positive. Citric acid is not assimilated. Tests for methyl red and Voges-Proskauer are negative. Maltose, lactate, malate, arginine and glutamate support growth as sole carbon sources. Glucose, lactose, mannitol, sorbitol, inositol, arabinose, fructose, sucrose, L-lysine, L-leucine and L-phenylalanine do not support growth. The cellular fatty-acid profile is outlined in Table 1. DNA G $+\mathrm{C}$ content is $63.3 \mathrm{~mol} \%$.

The type strain, DX5 $-10^{\mathrm{T}}$ (=CGMCC $1.3455^{\mathrm{T}}=\mathrm{JCM}$ $12573^{\mathrm{T}}$ ), was isolated from a sample of coastal sediment from the East China Sea of the Pacific Ocean.

\section{Acknowledgements}

Dr Y.-N. Wang, currently at the Tsinghua University, Beijing, PR China, was involved in the isolation of strain DX5 $-10^{\mathrm{T}}$. This work was supported by grants from National Natural Science Foundation of China (3040 0007) and Chinese Academy of Sciences (KSCX2-SW113). This paper is dedicated to the memory of Professor Hui-Fang Yang, who passed away in March 2005.

\section{References}

Buchan, A., Neidle, E. L. \& Moran, M. A. (2001). Diversity of the ring-cleaving dioxygenase gene $p c a H$ in a salt marsh bacterial community. Appl Environ Microbiol 67, 5801-5809.

Cho, J.-C. \& Giovannoni, S. J. (2004). Oceanicola granulosus gen. nov., sp. nov. and Oceanicola batsensis sp. nov., poly- $\beta$-hydroxybutyrateproducing marine bacteria in the order 'Rhodobacterales'. Int J Syst Evol Microbiol 54, 1129-1136.

Collins, M. D. (1985). Isoprenoid quinone analysis in classification and identification. In Chemical Methods in Bacterial Systematics, pp. 267-287. Edited by M. Goodfellow \& D. E. Minnikin. London: Academic Press.

Dai, X., Wang, Y.-N., Wang, B.-J., Liu, S.-J. \& Zhou, Y.-G. (2005). Planomicrobium chinense sp. nov., isolated from coastal sediment, and transfer of Planococcus psychrophilus and Planococcus alkanoclasticus to Planomicrobium as Planomicrobium psychrophilum comb. nov. and Planomicrobium alkanoclasticum comb. nov. Int J Syst Evol Microbiol 55, 699-702. 
Eguchi, M., Nishikawa, T., MacDonald, K., Cavicchioli, R., Gottschal, J. C. \& Kjelleberg, S. (1996). Response to stress and nutrient availability by the marine ultramicrobacterium Sphingomonas sp. strain RB2256. Appl Environ Microbiol 62, 1287-1294.

Eilers, H., Pernthaler, J., Glöckner, F. O. \& Amann, R. (2000). Culturability and in situ abundance of pelagic bacteria from the North Sea. Appl Environ Microbiol 66, 3044-3051.

Garrity, G. M., Bell, J. A. \& Lilburn, T. G. (2004). Taxonomic outline of the Prokaryotes. In Bergey's Manual of Systematic Bacteriology, 2nd edn, pp. 44-48, Release 5.0. New York: Springer. doi: 10.1007/ bergeysoutline200405

González, J. M. \& Moran, M. A. (1997). Numerical dominance of a group of marine bacteria in the $\alpha$-subclass of the class Proteobacteria in coastal seawater. Appl Environ Microbiol 63, 4237-4242.

González, J. M., Covert, J. S., Whitman, W. B. \& 8 other authors (2003). Silicibacter pomeroyi sp. nov. and Roseovarius nubinhibens sp. nov., dimethylsulfoniopropionate-demethylating bacteria from marine environments. Int J Syst Evol Microbiol 53, 1261-1269.

Kimura, M. (1980). A simple method for estimating evolutionary rates of base substitutions through comparative studies of nucleotide sequences. J Mol Evol 16, 111-120.

Kobližek, M., Béjà, O., Bidigare, R. R., Christensen, S., BenitezNelson, B., Vetriani, C., Kolber, M. K., Falkowski, P. G. \& Kolber, Z. S. (2003). Isolation and characterization of Erythrobacter sp. strains from the upper ocean. Arch Microbiol 180, 327-338.

Labrenz, M., Collins, M. D., Lawson, P. A., Tindall, B. J., Braker, G. \& Hirsch, P. (1998). Antarctobacter heliothermus gen. nov., sp. nov., a budding bacterium from hypersaline and heliothermal Ekho lake. Int J Syst Bacteriol 48, 1363-1372.

Labrenz, M., Lawson, P. A., Tindall, B. J., Collins, M. D. \& Hirsch, P. (2005). Roseisalinus antarcticus gen. nov., sp. nov., a novel aerobic bacteriochlorophyll $a$-producing $\alpha$-proteobacterium isolated from hypersaline Ekho Lake, Antarctica. Int J Syst Evol Microbiol 55, 41-47.

Macián, M. C., Arahal, D. R., Garay, E., Ludwig, W., Schleifer, K. H. \& Pujalte, M. J. (2005). Thalassobacter stenotrophicus gen. nov., sp. nov., a novel marine $\alpha$-proteobacterium isolated from Mediteranean sea water. Int J Syst Evol Microbiol 55, 105-110.

Marmur, J. (1961). A procedure for the isolation of deoxyribonucleic acid from microorganisms. J Mol Biol 3, 208-218.

Martínez-Cánovas, M. J., Quesada, E., Martínez-Checa, F., del Moral, A. \& Béjar, V. (2004). Salipiger mucescens gen. nov., sp. nov., a moderately halophilic, exopolysaccharide-producing bacterium isolated from hypersaline soil, belonging to the $\alpha$ Proteobacteria. Int J Syst Evol Microbiol 54, 1735-1740.

Pukall, R., Buntefuß, D., Frühling, A., Rohde, M., Kroppenstedt, R. M., Burghardt, J., Lebaron, P., Bernard, L. \& Stackebrandt, E. (1999).
Sulfitobacter mediterraneus sp. nov., a new sulfite-oxidizing member of the $\alpha$-Proteobacteria. Int J Syst Bacteriol 49, 513-519.

Rappé, M. S., Vergin, K. \& Giovannoni, S. J. (2000). Phylogenetic comparisons of a coastal bacteriophankton community with its counterparts in open ocean and freshwater systems. FEMS Microbiol Ecol 33, 219-232.

Saitou, N. \& Nei, M. (1987). The neighbor-joining method: a new method for reconstructing phylogenetic trees. Mol Biol Evol 4, 406-425.

Sorokin, D. Y. (1995). Sulfitobacter pontiacus gen. nov., sp. nov. - a new heterotrophic bacterium from the Black Sea, specialized on sulfite oxidation. Mikrobiologiia 64, 354-365.

Suzuki, T., Muroga, Y., Takahama, M. \& Nishimura, Y. (1999). Roseivivax halodurans gen. nov., sp. nov. and Roseivivax halotolerans sp. nov., aerobic bacteriochlorophyll-containing bacteria isolated from a saline lake. Int J Syst Bacteriol 49, 629-634.

Teske, A., Brinkhoff, T., Muyzer, G., Moser, D. P., Rethmeier, J. \& Jannasch, H. W. (2000). Diversity of thiosulfate-oxidizing bacteria from marine sediments and hydrothermal vents. Appl Environ Microbiol 66, 3125-3133.

Thompson, J. D., Gibson, T. J., Plewniak, F., Jeanmougin, F. \& Higgins, D. G. (1997). The CLUSTAL X windows interface: flexible strategies for multiple sequence alignment aided by quality analysis tools. Nucleic Acid Res 25, 4876-4882.

Urbance, J. W., Bratina, B. J., Stoddard, S. F. \& Schmidt, T. M. (2001). Taxonomic characterization of Ketogulonigenium vulgare gen. nov., sp. nov. and Ketogulonigenium robustum sp. nov., which oxidize L-sorbose to 2-keto-L-gulonic acid. Int J Syst Evol Microbiol 51, 1059-1070.

Van de Peer, Y. \& De Wachter, R. (1994). TREECON for windows: a software package for the construction and drawing of evolutionary trees for the Microsoft Windows environment. Comput Appl Biosci 10, 569-570.

Van Trappen, S. V., Mergaert, J. \& Swings, J. (2004). Loktanella salsilacus gen. nov., sp. nov., Loktanella fryxellensis sp. nov. and Loktanella vestfoldensis sp. nov., new members of the Rhodobacter group, isolated from microbial mats in Antarctic lakes. Int J Syst Evol Microbiol 54, 1263-1269.

Zhang, D., Yang, H., Zhang, W., Hung, Z. \& Liu, S.-J. (2003). Rhodocista pekingense sp. nov., a cyst-forming phototrophophic bacterium from a municipal wastewater treatment plant. Int J Syst Evol Microbiol 53, 1111-1114.

Zubkov, M. V., Fuchs, B. M., Archer, S. D., Kiene, R. P., Amann, R. \& Burkill, P. H. (2001). Linking the composition of bacterioplankton to rapid turnover of dissolved dimethylsulphoniopropionate in an algal bloom in the North Sea. Environ Microbiol 3, 304-311. 